\title{
Cooperation between Medicine and Food Supervisory Agency (BPPOM) in Padang and Institutions of Food Processing of Medicinal Medicine and Cosmetics of Indonesian Ulama Council (LPPOM MUI) in West Sumatera Province Concerning the Halal Status of Packaged Food Products
}

\author{
Dilla Ayuna Letri; Yaswirman; Zefrizal Nurdin \\ Faculty of Law, University of Andalas Padang, Indonesia
}

http://dx.doi.org/10.18415/ijmmu.v6i5.1074

\begin{abstract}
Indonesia is a country with muslim mayorities, therefore the state must protect the community to make ends meet, including of halal food according to the faith of every Muslim. In reality, many products in the community are not guaranteed with halal licence. In Indonesia, there is many packaged food products with unclear halal status, producer of these products is needed to be safe for consumption by all people, especially those who are Muslim. Writing this thesis uses an empirical juridical research approach method. The data collected is in the form of primary data obtained from related parties in the supervision of packaged food products, as well as secondary data obtained from primary, secondary and tertiary legal materials. From the results of the study it was found that the authority of the BPOM in conducting oversight of the halal packed food products contained in 2 (two) things, namely: supervision of premarket and post market. The authority of LPPOM MUI in conducting supervision is carried out by Halal Auditors and Internal Halal Auditors in a company. Until now, BPOM still has not cooperated with LPPOM MUI or BPJPH as stated in a cooperation agreement. So that these agencies only work in accordance with the tasks specificly in the regulations made by their respective agencies and until now it is still difficult to create good coordination or cooperation, including in overseeing the halal of packed food product.
\end{abstract}

Keywords: Cooperation; BBPOM; LPPOM MUI; Halal; Packed Food

\section{Introduction}

Basic human needs are clothing, food and shelter. Food is a basic human need which is the basic right of every Indonesian people as mentioned in the Constitution 1945. Food must be available all times, safe, with good quality, nutritious and diverse at prices that are affordable by people to purchase. To achieve all of that, a food system needs to be implemented that provides protection, both for those who produce and consume food, and appropriate with the faith of every Muslim. 
Indonesia is a country with a Muslim population, therefore the state must protect the community to make ends meet, including the needs of halal food in accordance to the faith of every Muslim. In Law Number 8 of 1999 concerning Consumer Protection, Article 4 (a):

"Consumer rights are the right to comfort, security and safety in buying goods and / or services".

This article states that every consumer, including consumers who are Muslim, is entitled to get goods that are comfortable and safe for consumption by him. The understanding of comfortable and safe for Muslim consumers is not contrary to the rules of the Islamic religion in this case is halal.

Furthermore, Article 4 (c) states that:

"Consumers are also entitled to true, clear and honest information about the conditions and guarantees of goods and / or services".

This article shows that the halal label affixed by the manufacturer to the packaging product must be true and honest. Thus the manufacturer does not carelessly claim that the product is halal, before going through halal testing.

To find out the halal and suitability of an item, a specific study is needed that requires multidisciplinary knowledge, such as knowledge in the fields of food, chemistry, bicomia, industrial engineering, biology, pharmacy and understanding of the Shari'a. The reality is that many products circulating in the community are not all guaranteed halal, even though the producer state that the marketed products are halal.

At present the Indonesian Food and Drug Administration and the Indonesian Ulema Council (hereinafter referred to as LPPOM MUI) provides halal certificates to producers who voluntarily register their products for auditing by LPPOM MUI. That way the products circulating among the people, especially packaged food products that will be consumed by Muslim consumers, expected to be truly halal, not just the inclusion of a label, but it has been tested at LPPOM MUI and obtained a halal certificate.

Based on the team's search results that many products inclusion the halal label illegally and with this following facts :

1. Packaged food products just receive MUI halal certificates for several types of products but have claimed all products that they produce are halal.

2. Packaged food products that have received a MUI halal certificate but after the validity is expires, they does not renew it, but the halal label on the package is still in use.

3. Packaged food products that include halal labels without going through an inspection by LPPOM MUI or in other words the packaged food products have not received halal certificates from MUI but have included halal labels on their packages. Even though halal certificates and halal labels are interrelated. Permit for labeling halal on the packaging is only given if the product has obtained halal certificate from MUI. This means that business actors have included halal labels in accordance with their perceptions of halal or haram. 
In Indonesia, there is many outstanding packaged food products with unclear halal status, supervision of these products is needed, so that it is safe for consumption by all people, especially those who are Muslim. Therefore, the President has formed an institution that is given certain tasks in terms of supervision of drugs and food, called the Center for Drug and Food Control (hereinafter referred to as BPPOM). This body is coordinated by the Minister of Health and the Minister of Social Welfare who are assigned the task of drug and food control in Indonesia which is formed in each province throughout Indonesia.

At this time after the issuance of Law Number 33 of 2014 concerning Halal Product Guarantee, the LPPOM MUI and BBPOM as halal certification auditing agencies will cooperate with the Halal Product Guarantee Agency (hereinafter abbreviated as BPJPH) in accordance with Article 7 of Law Number 33 of 2014, which reads:

"In exercising authority as referred to in Article 6, BPJPH cooperates with:

a. Related ministries and / or institutions;

b. $\mathrm{LPH}$; and

c. MUI"

Comparing the authority of the Center for Drug and Food Control (BPPOM) with the Indonesian Ulema Council for Drug and Food Research Institute (LPPOM MUI), each party has different authority, where BPPOM has the right to give halal labels for halal products and has declared passed the verification according to their own procedures while LPPOM MUI has the right to issue halal certificates based on the permission to list halal labels on food products that have been given by BBPOM.

But in reality in 2014, the two institutions signed a memorandum of understanding regarding halal certification and halal labeling issued by BPPOM and LPPOM MUI. The memorandum stated that the halal label issued by BPPOM must be certified in advance by LPPOM MUI. To support this, the two institutions should absolutely exchange information and cooperate with each other before and after the circulation of the packaged food products.

with the existence of several related institutions and applicable regulations regarding the halal status of a packaging product, there are still many cases of products without a halal label. Therefore, based on the background description above, the authors are interested in conducting research under the title "Cooperation of the Center for Drug and Food Supervision (BBPOM) in Padang and the Institute of Food and Drug Research and Cosmetics of the Indonesian Ulema Council (LPPOM MUI) of West Sumatra Province Concerning The Halal Status Of Packaged Food Products"

\section{Research Methods}

The method used in this thesis research is empirical juridical research, which is research based on field research to get primary data in the field of law. The specifications of this study are descriptive analysts, because this study is expected to obtain data that clearly illustrate what is discussed in this study. The type of data used in this study are primary and secondary data, where secondary data consists of Primary, Secondary and Tertiary Legal Materials. The data collection techniques used for research in the field are interviews and study of documentation documents. While the data obtained from this research will be analyzed using qualitative methods, namely analysis of data without using statistical formulas 
because the data used are not in the form of numbers. Thus what is used is only by logical explanation of the sentence based on the rules and opinions of experts.

\section{Research Results and Discussions}

Authority Of The Center For Drug And Food Supervision (BBPOM) In Padang In Supervising The Halal Status Of Packaged Food Products

One proof of the halal of the product is safe for consumption is the installation of halal labels on food products in the packaging, so that the halal label can provide protection to Muslim consumers and Muslim consumers feel safe in consuming the packaged products they use. Likewise for non-Muslim consumers will also feel safe in consuming packaged food products.

Based on the results of an interview with Mr. Yon Firman as a staff of Young Experts in the Field of Information and Communication of BBPOM in Padang, which stated that base on consumer protection, especially for Muslims who are packaged of food products in order to ensure their halal status, the provisions of Article 8 letter h Law Number 8 of 1999 concerning Consumer Protection, it is determined that business actors are prohibited from producing and / or trading goods and / or services that do not comply with the provisions of halal production, as stated in the "halal" statement stated on the label.

With the halal label listed on the food packaging, Muslim consumers should have received protection that the halal label is in accordance with existing regulations, so that the achievement of the rights of consumers is entitled to get true, clear and honest information about the conditions and guarantees of goods and / or service. As a government agency stated that it is not easy to determine that the product in the package is halal or haram, because it requires special knowledge and must use sophisticated equipment to examine what ingredients are used in the food product.

Based on the results of an interview with Mr. Yon Firman, that Food and Drug Control has broad and complex aspects of the problem. Therefore a comprehensive supervision system is needed, since the beginning of the process of a product until the product is circulating in the community. This aims to reduce the smallest possible risk. Drug and Food Control is carried out by SISPOM (Drug and Food Control System) which is summarized in three layers of supervision namely:

a. Sub-system of producer supervision

Internal control system by producers through the implementation of good production methods or good manufacturing practices so that any form of deviation from quality standards can be detected early. The producer is legally responsible for the quality and safety of the products it produces.

b. Consumer surveillance sub-system

The supervision system by the public (consumers) is carried out through raising awareness and increasing knowledge about the quality of the products it uses and ways of using rational products. 
c. Sub-system of government oversight / POM

Government monitoring system through regulation and standardization both in terms of safety assessment, efficacy and quality of products before being allowed to circulate in Indonesia by inspection, sampling and testing samples in the laboratory for products in circulation as well as public warnings supported by law enforcement.

From the overall duties, functions and authority of BBPOM that have been explained above, the authority of BPOM and central BPOM in general in conducting supervision of food products, especially those in packaging, is found in 2 (two) things, namely:

\section{a. Pre-Market Supervision}

Namely supervision at the time of conducting an audit of the implementation and fulfillment of Good Food Production Methods (CPPOB). If a product has passed the audit and already has a Halal certificate from the MUI, the product can put the halal logo on the packaging.

\section{b. Post Market Supervision}

Namely with a number of checks, including:

1) Inspection of production facilities used in the context of the application of Good Food Processing Methods.

2) Inspection of packaging food distribution facilities;

3) Supervision of food intensification ahead of religious holidays / new year, namely supervision of the inclusion of halal labels / logos on food packaging.

Authority of the Food and Drug Assessment and Cosmetics Agency of the Indonesian Ulema Council (LPPOM MUI) in Supervising the Halal Status of Packaged Food Products

In Islam, safe packaged food is halal packaged food, that is halal from the ingredients, how to process it, and halal in how to obtain it. A product that will obtain a halal certificate on its product must first be audited by the LPPOM MUI Halal Auditor. in LPPOM MUI West Sumatra Province there have been 17 Halal Auditors consisting of academics in West Sumatra and from BBPOM Padang. The forms of supervision conducted by the LPPOM MUI Halal Auditor Team are as follows:

1. Inspection of the Halal Assurance System from the producer;

2. Conduct an inspection to the field whether the SJH carried out by the producers is in accordance with Islamic law;

3. Checking the materials used, production sites and production equipment used. 
In order to supervise companies that have halal certificates, LPPOM MUI hands over all such supervision to the Internal Halal Auditor (hereinafter referred to as AHI) as an extension of his hand. Internal Halal Auditors (AHI) are employees of the producers who are appointed as special employees who coordinate the implementation of the Halal Assurance System $(\mathrm{SJH})$, ranging from when purchasing materials, storing food in warehouses to the process of making food. The supervision carried out by AHI is carried out by 1 person from the company's employees who aims that if the Halal Assurance System is carried out by one person, the results of the production will always be maintained and halal guaranteed.

Based on the interview with Mr. Syaifullah explained that the change, the addition of raw materials, changes in production processes, management, change of supplier, the change in the formula foodstuffs, are the things that belong to the form of supervision should be done by a Halal Auditor Internal (AHI) in a company which must then be communicated to the LPPOM MUI. The form of supervisory activities carried out by AHI includes a halal warehouse audit, a halal audit of production, and a halal audit for purchases. AHI surveillance activities in the scope of this warehousing is an important activity in order to avoid contamination of materials that can cause loss of halal product.

Form of Cooperation between the Center for Drug and Food Supervision (BBPOM) in Padang and the Institute for Drug and Cosmetics Food Assessment of the Indonesian Ulema Council (LPPOM MUI) of West Sumatra Province in Supervising the Halal Status of Packaged Food Products

As a form of implementation of the provisions in the Law on Food, the Indonesian National Drug and Food Control Agency which has been delegated by the Ministry of Health has established a collaboration with the Indonesian Ulema Council in this case carried out by the Indonesian Food and Drug Research Institute (LPPOM MUI). The Cooperation Charter has been signed since June 21, 1996. In the cooperation charter LPPOM MUI handles the audit and product halal assurance issues. Meanwhile, the Indonesian Food and Drug Administration Agency has the duty to oversee food in the aspects of safety, quality and nutrition.

However, in practice in the field according to Mr. Yon Firman, since the signing of the Cooperation Charter it is still unclear how the procedure for implementing halal product guarantees is carried out, both in terms of the role and function of each of the relevant agencies. Because in the implementation of these agencies only work in accordance with the authority specified in the regulations made by their respective agencies. So it is still difficult to create a good coordination or cooperation, including in monitoring halal food product.

In 2013 there is also a form of a Memorandum of Understanding between the National Agency of Drug and Food Center by the Indonesian Ulema Council with No. HK.08.1.53.05.13.2779 / Number: MOU04 / Dir / LPPOM MUI / V / 13 on Cooperation Inclusion Halal Description on Label Processed food. In Article 3 of the Memorandum of Understanding it is explained that joint inspection or audit conducted by BPOM and LPPOM MUI is still carried out based on the authority of each institution, where BPOM checks the part in fulfilling CPPOB while LPPOM MUI checks Halal Assurance System owned by the company, which is one of the points in the Halal Assurance System that already has a letter of recommendation fulfilling CPPOB. According to Mr. Syaifullah until now this Memorandum of Understanding is still used by West Sumatra LPPOM MUI in granting halal certification in West Sumatra.

Regarding the future collaboration after the enactment of the JPH Law, in July 2018 the Head of the Central BPJPH, Mr Sukoso, visited the Central POM RI in Jakarta. At that time, Mr. Sukoso conveyed the proposal of several cooperation points that could be carried out with BPOM RI, including: 
a. In terms of information technology in Halal Information Systems;

b. Halal label mechanism and non-halal information;

c. Permission mechanism for halal labeling;

d. Coordination of supervision and coaching, publication of the results of joint supervision, and

e. Procedure for revoking halal certificates;

He continued, until this government regulation had been ratified by the president until now there had been no formal agreement in the form of MoU or cooperation agreement made between BPJPH and BPOM. In this case BBPOM in Padang felt that they had worked optimally in supervising the products in circulation, and so did the LPPOM MUI who felt they had also worked optimally in the process of providing their halal certificates.

\section{Conclusion}

The authority of POM in supervising the halal of packaged food products is found in 2 (two) things, namely: pre-market and post-market supervision. The authority of LPPOM MUI in conducting supervision is carried out by MUI Halal Auditors and Internal Halal Auditors (AHI) from the company. Until this government regulation has been passed, there has been no formal agreement in the form of MoU or cooperation agreement made in terms of product halal supervision. So at this time, these agencies carry out supervision in accordance with the tasks specified in the regulations made by their respective agencies and until now it is still difficult to create good coordination or cooperation, including in overseeing the halal of food products.

\section{Suggestion}

For related institutions such as BPOM both central and BBPOM in regions with LPPOM MUI must make clear coordination or cooperation related to the supervision of halal food packaging products, because of the many circulation of packaging products that do not include halal labels so that people do not know whether the products consumed are halal or not.

\section{References}

\section{Books}

Abdullah, Thamrin dan Francis Tantri, Marketing Management, PT. Raja Grafindo Pesada, Jakarta, 2012.

Ali, Zainuddin, Legal Research Methods, Sinar Grafika, Jakarta, 2009.

Azwar, Sarifuddin, Research Methods, Pustaka Pelajar, Yogyakarta, 1998.

HS Salim dan Elies Septiana Nurbani, Application of Theory to Thesis and Dissertation Research, Raja Grafindo Persada, Jakarta, 2013.

Fida', Yazid Abu, Haram Halal Food Encyclopedia, Cetakan Pertama, Pustaka Arafah, Solo, 2014. 
Nuryati, Sri, Is your food Halal?, PT. Aqwam Media Profetika, Solo, 2008.

Qardhawi, Yusuf, Halal and Haram in Islam, Era Intermedia, Surakarta, 2011.

Zulham, Revised Edition of Consumer Protection Law, Cetakan ke-2, Prenada Media Group, Jakarta, 2016.

\section{Legislation}

Civil Code (KUHPerdata).

Law Number 8 of 1999 concerning Consumer Protection.

Law Number 18 of 2012 concerning Food.

Law Number 33 of 2014 concerning Halal Product Guarantee

Government Regulation Number 69 of 1999 concerning Food Labels and Advertisements.

Government Regulation Number 31 Year 2019 concerning Implementation Regulations Act Number 33 Year 2014 concerning Guarantee of Halal Products

Decree of the Minister of Religion of the Republic of Indonesia No. 518 of 2001 concerning Guidelines and Procedures for Examination and Determination of Halal Food.

Regulation of the Head of the POM Agency No. 12 of 2016 concerning Registration of Food Products.

\section{Journal}

Hernawan, The Importance of Including Halal Labels in Food Product Packaging as a Form of Legal Protection for Muslim Consumers, Journal of Legal and Social Vol. 1 No. 2, 2013, Faculty of Law, University 17 August 1945, Samarinda, 2013.

\section{Interview}

Interview with Mr. Syaifullah Zoelkiar, LPPOM MUI, on Monday, April 22, 2019, at 14.00

Interview with Mr. Yon Firman, as PFM Young Expert in Consumer Information Services, on Tuesday 2 July 2019, at 10:00

\section{Copyrights}

Copyright for this article is retained by the author(s), with first publication rights granted to the journal.

This is an open-access article distributed under the terms and conditions of the Creative Commons Attribution license (http://creativecommons.org/licenses/by/4.0/). 